\title{
Investigating the Factors Influence Adoption of Internet Banking in Malaysia: Adopters Perspective
}

\author{
Yong Hoe Hong ${ }^{1}$, Boon Heng Teh ${ }^{1}$, Gowrie Vinayan ${ }^{1}$, Chin Hooi Soh ${ }^{1}$, Nasreen Khan ${ }^{1} \&$ Tze San Ong ${ }^{2}$ \\ ${ }^{1}$ Faculty of Management, Multimedia University, Malaysia \\ ${ }^{2}$ Faculty of Economics \& Management, University Putra, Malaysia \\ Correspondence: Gowrie Vinayan, Faculty of Management, Multimedia University, 63100 Cyberjaya, Selangor, \\ Malaysia. E-mail: gowrie.vinayan@mmu.edu.my
}

Received: June 20, 2013

Accepted: August 9, 2013

Online Published: September 18, 2013

doi:10.5539/ijbm.v8n19p24

URL: http://dx.doi.org/10.5539/ijbm.v8n19p24

\begin{abstract}
The main purpose of this research is to investigate the factors that influence adopters to take up the Internet banking services in Malaysia. The sampling units in this survey are the adopters of Internet banking who were using it for at least six months. A total of 116 useable questionnaires was coded and analyzed by using SPSS software. Statistical methods like descriptive analysis, factor analysis and regression analysis were used in this research. The regression results showed that Complexity, Security and Ccustomer Experience were the influencing factors of Internet banking services. However, Individual Characteristics was found to be partially influencing the adopters in their decision to adopt the Internet banking facilities.
\end{abstract}

Keywords: internet banking adoption, complexity, security, customer experience, individual characteristics

\section{Introduction}

Internet banking plays an increasingly important role in the banking industry. Internet banking can be described as the banking transactions provided by a particular bank to its users through a computer. In Malaysia, Maybank pioneered to provide online banking services to their users through its web portal. Prior to 2002, only the foreign banks were allowed to provide online banking transactions in Malaysia. According to Association of Banks in Malaysia (ABM), the commercial banks have been investing substantially in services terminal and e-banking centers, as well as infrastructure for Internet and tele-banking.

During the initial stages when the Internet banking revolution commenced in Malaysia in year 2000, the growth of Internet banking has been very encouraging and consequently, more and more banks began to provide Internet banking services to their customer (Perumal \& Vignesen, 2004). However, the widespread acceptance or adoption of Internet banking is, still lacking. According to The Edge, (2011) the penetration rate of Internet banking subscribers is still low and stands only at $4.10 \%$.

In recent years, most of the Internet banking adoption studies (1999-2011) only investigated the respondents "intention to adopt" (Tan \& Teo, 2000; Shih \& Fang, 2004 \& Hernandez \& Mazzon, 2007) or comparison between adopters and non-adopters (Sathye, 1999; Suganthi et al., 2001; Gerrard and Gumingham, 2003; Akinci et al., 2004; Chan \& Lu, 2004; Laforet \& Li, 2005; Lee et al., Gerrard et al., 2006; Awamleh \& Fernandez, 2006; Polasik \& Winsniewski, $2009 \&$ Foon \& Fah, 2011) rather than investigating the Internet banking adopters. Without a good understanding about the adopters of Internet banking, it would be challenging to understand the contributing factors that will cause the Internet banking adopters continue to adopt Internet banking. The respondents of the Internet banking study should be the actual Internet banking adopters rather than people who have the "intention to adopt". It is because the intention to adopt is viewed as self reported. According to Tan \& Teo, (2000), Chan \& Lu, (2004) the study on Internet Banking can only be measured when the Internet banking adopters have reached a critical mass. Since 2000, the Internet banking adoption has been intensively investigated by various scholars in the world, it has deemed to have reached the critical volume adopters. However, recently, researchers have shown a decreased interest in the Internet banking study for no apparent reason. Hence, there should be more researches on the Internet banking adoption be conducted to explore and unearth the underlying contributory factors and to indirectly spur the interest in this area of researach. The purpose of this research is to investigate the factors that influence adopters to adopt Internet banking. 


\section{Literature Review}

Previous studies have reported that Perceived Security, Complexity, Customer Experience, and Individual Characteristics are important factors to influence the adoption of Internet Banking. There were a considerable amount of literature has been published on these factors in previous studies. This study, therefore, is using these factors to investigate the adoption of Internet banking in Malaysia.

\subsection{Perceived Security}

The Perceived Security factor was seen as a very strong predictor influence by the Internet banking users in Poland (Polasik \& Wisniewski, 2009). In a study by Lee et al. (2003), Perceived Security was found to be having a significant effect on computer banking adoption. In a study by Sabbagh and Molla (2004) carried out in Oman, Perceived Security and Trust were found to be the two top issues inhibiting the adoption. Lee at al. (2005) also found the Transaction Security and Size of the Provider to have significant effect on the adoption of the Internet banking. In a study conducted by Awamleh and Fernandez (2006) where an examination on the factors that influencing the intention to adopt/continue to use the Internet banking among users and non-users in non-OECD countries were made, the Perceived Security was found to have significant difference between Internet banking users and non-users. Gerrard et al. (2006) used qualitative study to understand the reasons behind the bank consumers are not using Internet banking. Their research findings showed that the main contributing factor as to why the bank users are not using the Internet banking is Security (33.4\%), followed by a Lack of Perceived Need (24.3\%), Insufficient Knowledge on the service (14.4\%), Inertia (10.4\%), and others. In their research, Hernandez and Mazzon (2007) found that Security has a significant correlation with the use of Internet banking. However, a study by Laforet and $\mathrm{Li}$ (2005), shows that Security was found not to differ significantly between online banking adopters and non-adopters. Thus, the following hypothesis is suggested:

H1: Security has an influence on adoption Internet banking.

\subsection{Complexity}

Gerrard and Gumingham (2003) conducted a survey covering 111 adopters and 129 non-adopters in Singapore in order to understand the diffusion of Internet banking and measure the characteristics of adopters and non-adopters. Their survey found that there is a difference between adopters and non-adopters in the Complexity factor. Lee et al. (2003) employed the effects of isolating factors on the consumers' adoption towards computer banking and ATM by using two-step estimation approach. Their study showed that the factor Complexity had significant effects on computer banking adoption. According to Kolodinsky et al. (2004) and Ndubishi \& Sinti (2006), the Complexity factor plays a major role in the adoption of electronic banking. Constrastingly, in their study, Tan \& Teo (2000) found that all the factors they have tested were significantly affecting Internet banking adoption except Complexity, Sbjective norm, and Technology support. Also, in a study by Brown et al. (2004), the research showed that Internet banking adoption in Singapore and South Africa were not affected by complexity. In Malaysia, Norazah (2010) study result shows that adoption of Internet banking by Malaysian consumers was not significantly influenced by the Complexity factor.Thus, the following hypothesis are suggested:

$\mathrm{H} 2$ : Complexity has an influence on adoption of Internet banking.

\subsection{Customer Experience}

"A customer experience consists of hundreds of small activities that create perceptions in the minds of customers" (Zafar et al., 2012, p. 11). A research conducted in China to investigate the consumer's attitude towards online banking research explained that there was a significant difference between online banking users and non-users in computer and technical experience. However, the difference in personal banking experience was found not to be significant between online banking adopters and non-adopters (Laforet and $\mathrm{Li}, 2005$ ). According to Brown et al. (2004), customer experience in the Internet was found to affect the adoption of Internet banking in Singapore (Tan and Teo 2000) but not in South Africa. Karjaluoto et al. (2002) conducted a survey to determine the factors that will influence the attitude towards online banking and the potential users' intention to use online banking services. The survey results shows that prior computer experience, individual banking experience and attitude towards computer were positively associated with online banking usage. Thus, the following hypothesis are suggested:

H3: Customer experience has an influence on adoption of Internet banking. 


\subsection{Individual Characteristics}

Many studies have used demographic factors or individual characteristics as their independent variables to predict the adoption of Internet banking and these studies confirmed that the young, educated, and wealthy individuals are the groups that are most likely to adopt the internet banking. Shao (2007) successfully identified 54 articles on Internet banking studies from 1998 to 2006. His studies shows that the demographic factors are one of the most frequent factors and $51.9 \%$ of the articles used demographic variables as their determinants of Internet banking adoption and usage. Polatoglu \& Ekin (2001) investigated the satisfaction level on the use of online banking services and the factors that influence users' acceptance of Internet banking in Turkey. Their study found that those who are young, higher in education and income groups were more likely to be the adopters of Internet banking. The study by Lassar et al. (2005) shows that the income level was significantly related to online banking adoption; and the online banking adoption was not significantly affected by age and education level. Jaruwachithanakul and Fink (2005) conducted a study using age, gender, educational levels, and income as moderating factors. In their study, the gender, educational levels and income were found to significantly influence the adoption of Internet banking. Age, however, was found not to have a significant relationship with the adoption of Internet banking. Hernandez and Mazzon (2007) found that the adoption of Internet banking was associated with particular personal characteristics especially age and education level. Contrastingly, Laforet and $\mathrm{Li} \mathrm{(2005)}$ found their results indicated that the adoption of Internet banking is not necessarily dominated by males and highly educated. This again is contrasting with the electronic banking studies in the Western countries. These findings are further supported by Lee et al. (2003) where their research found that age and education level were not significantly associated with the adoption of online banking. Income, meanwhile, was found marginally significantly related to the adoption of computer banking. Thus, the following hypothesis is suggested:

H4: Individual characteristics have an influence on adoption of Internet banking.

\subsection{Conceptual Framework}

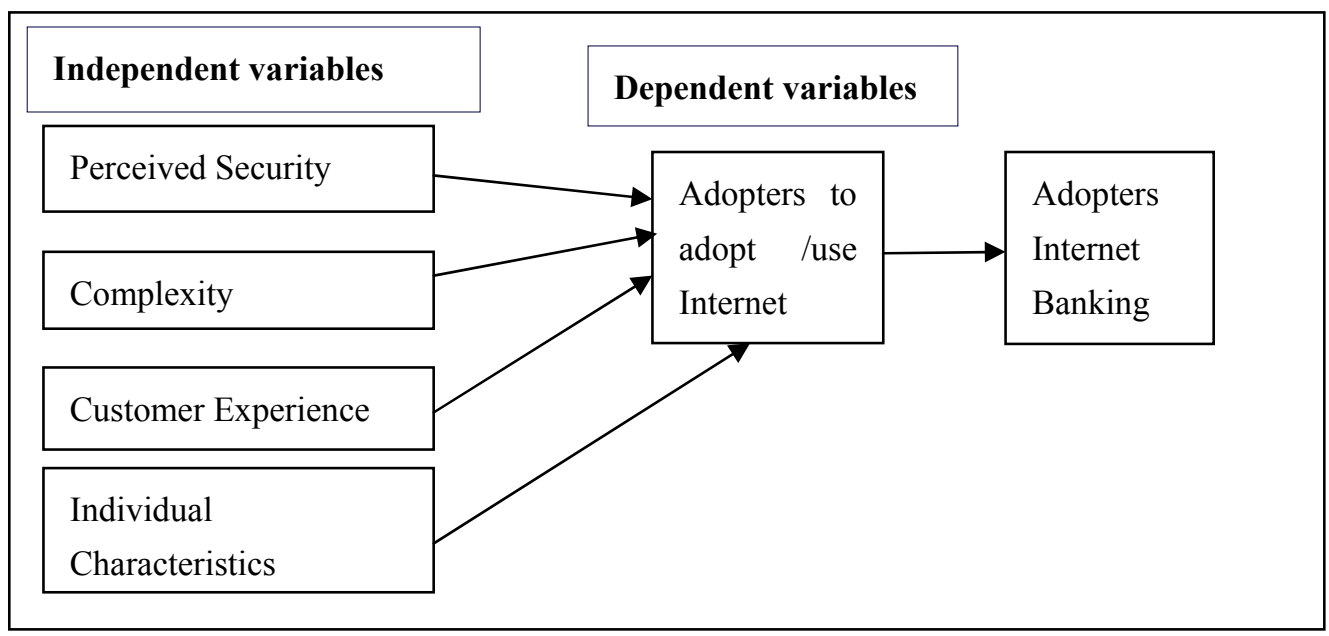

Figure 1. Conceptual framework

Figure 1 shows the conceptual framework for this research. In this framework, the four factors or independent variables are Perceived Security, Complexity, Ccustomer Experience, and Individual Characteristics.

\section{Methodology}

\subsection{Research Method/Approach}

This is a descriptive research that investigates the factors that influence the adopters to adopt the Internet banking in Malaysia. A cross-sectional survey research had been chosen as the research approach where primary data were collected by requesting the respondents to fill up the questionnaires.

\subsection{Measurement}

The questionnaire was designed in line with the aim of the research. It consists of two parts; Part 1: the questions in this section will state the respondents' agreement on whether the attributes are part of the factors 
that influence their adoption of Internet banking. It is measured by Likert scale ranging from 1 (strongly disagree) to 7 (strongly agree). Part 2: is about the demographic profile of the respondents. In this research, the questionnaire was purely based on the previous instrument developed by various researchers. Items to measure the complexity were adapted from Tan \& Teo (2000), items to measure security were adapted from Hernandez \& Mazzen (2007) and the items of customer experiences were adapted from Karjaluoto et al. (2002).

\subsection{Sampling Procedure}

The population in this research consists of the adopters of Internet banking in Malaysia. The sampling unit identified the relevant people to be surveyed. In this study, the sampling unit was the knowledge-workers of the MSC (Multimedia Super Corridor) Malaysia status companies. This group was chosen mainly because of the respondents' likelihood of possessing computer knowledge and the accessing to the Internet, which are essential to use the Internet banking services. Ten MSC status companies in Cyberjaya, Malaysia constitute the sampling frame for this study. Cyberjaya is the heartland of MSC status company and most of the companies are located in this area. According to MSC Malaysia (2008), more than $89 \%$ of the staff of MSC status companies are categorized as knowledge workers holding high-value jobs.

\subsection{Data Collection}

Two hundred questionnaires were distributed to ten MSC Malaysia status companies in Cyberjaya. For the data collection, the respondents were screened based on whether they have ever conducted Internet banking transactions or not, only those who have previously conducted Internet banking transactions for at least six months. A total of 134 questionnaires were collected from these ten companies but only 116 completed questionnaires were analyzed.

\subsection{Data Analysis}

The software used in analyzing the data was the commonly used Statistical Package of Social Science (SPSS). The statistical analysis includes descriptive analysis, factor analysis, and regression analysis.

\section{Results and Discussion}

\subsection{Descriptive Analysis}

Table 1. Profiles of the adopters

\begin{tabular}{|c|c|c|}
\hline Variables & Frequency & Percent $(\%)$ \\
\hline \multicolumn{3}{|l|}{ Gender } \\
\hline Male & 68 & 58.6 \\
\hline Female & 48 & 41.4 \\
\hline \multicolumn{3}{|l|}{ Age } \\
\hline$<21$ & 1 & 0.9 \\
\hline $21-30$ & 49 & 42.2 \\
\hline $31-40$ & 53 & 45.7 \\
\hline $41-50$ & 13 & 11.2 \\
\hline \multicolumn{3}{|l|}{ Income } \\
\hline $1000-3000$ & 15 & 12.9 \\
\hline $3001-5000$ & 45 & 38.8 \\
\hline $5001-7000$ & 40 & 34.5 \\
\hline $7001-9000$ & 11 & 9.5 \\
\hline$>9000$ & 5 & 4.3 \\
\hline \multicolumn{3}{|c|}{ Education Level } \\
\hline Certificate & 0 & 0 \\
\hline Diploma & 38 & 32.8 \\
\hline Degree & 65 & 56.0 \\
\hline Master & 13 & 11.2 \\
\hline
\end{tabular}

Table 1 shows that the respondents comprised of $58.6 \%$ males and $41.4 \%$ females. The majority of respondents possess Bachelors degree (56\%), and their monthly income is between RM3001-5000 (38.8\%), and they are from the ages of $31-40(45.7 \%)$. 
Table 2. Number of years using internet banking

\begin{tabular}{ccc}
\hline & Frequency & Percent $(\%)$ \\
\hline$<1$ year & 4 & 3.4 \\
1-3 years & 35 & 30.2 \\
4-6 years & 53 & 45.7 \\
7-9 years & 17 & 14.7 \\
$10-12$ years & 7 & 6.0 \\
\hline
\end{tabular}

From table 2, the results showed that $45.7 \%$ of the respondents are using Internet banking between 4-6 years, and then followed by $1-3$ years $(30.2 \%)$. This indicates that the adopters in this study are mostly early and late majority.

\subsection{Factor Analysis}

Table 3. Factor loading

\begin{tabular}{ccc}
\hline Variables & Items & Adoption \\
\hline Complexity & The difficult to conduct & 0.807 \\
& The complexity procedure & 0.843 \\
Security & Transaction security & 0.626 \\
& Data security & 0.806 \\
& One time password security system & 0.723 \\
Customer Experience & Internet experience & 0.759 \\
& Computer experience & 0.731 \\
& Prior electronic banking experience & 0.798 \\
Individual characteristics & Prior branch banking experience & 0.814 \\
& Influenced by gender & 0.517 \\
& Influenced by education & 0.549 \\
\hline
\end{tabular}

Table 3 shows the factor loading for Complexity, Security, Customer Experience, Individual Characteristics. The value of Kaiser-Meyer-Olkin (KMO) must be above 0.5 (Mathotra, 2007). In this study, all the variables KMO values are above 0.5 .

\subsection{Regression Analysis}

Table 4. Regression analysis

\begin{tabular}{llllll}
\hline Variables & Hypotheses & F value & Beta & t-value & Significance \\
\hline Complexity & H1 & 4.623 & 5.612 & 19.953 & $\mathbf{0 . 0 1 2}$ \\
Security & $\mathrm{H} 2$ & 3.098 & 4.314 & 5.812 & $\mathbf{0 . 0 3 0}$ \\
Customer Experience & $\mathrm{H} 3$ & 2.516 & 3.934 & 6.280 & $\mathbf{0 . 0 2 6}$ \\
Individual Characteristics & $\mathrm{H} 4$ & 3.660 & 5.757 & 8.634 & $\mathbf{0 . 0 0 4}$ \\
\hline
\end{tabular}

Table 4 presents the regression analysis result for these four hypotheses. The result showed that Complexity, Security, Ccustomer Experience and Individual Characteristics are significantly influencing the adoption of Internet banking. Complexity in terms of difficulty to conduct and complexity procedure was found to influence the adopters to adopt Internet banking. This mainly due to the adopters preferred easy ways or procedures to 
carry out the Internet banking services. Perceived security in terms of transaction and data is also found to strongly influence the adoption of Internet banking. This is mainly due to most of adopters are very concerned about the fraud of Internet banking transactions and lack of their privacy information and data. Customer experiences are also influenced the adoption of Internet banking. That goes to show that, that once the adopters are willing to adopt, they will perceive Internet banking as a good platform for them to do a banking transactions. For individual characteristics, income (Sig-value $=0.000)$ and education $($ Sig-value $=0.043)$ are significantly influencing the adoption of Internet banking. However, age (sig-value $=0.110)$ and gender $($ Sig-value $=0.272)$ are not significantly influencing the adoption of Internet banking. This result was quite similar to previous studies.

\section{Managerial Implications}

The result of this research indicates that the security of online banking still remain as the main concern among Internet banking adopters; it has become a major barrier for bank consumers in not adopting and using Internet banking. A reasonable approach to tackle this issue could be the continuous effort of the policy makers to develop more effective practices and collaborate with relevant agencies to handle security infringement incidences. If the risk of security can be minimized, the bank customers will be more confident to adopt Internet banking. Recently, some service providers in Malaysia introduced "hardware token" or "security device" to ensure adequate security measures observed on Internet banking transactions. It will be a useful safeguard for Internet banking activities. Besides, the policy maker and service providers should come out with more protection policies to ensure the internet banking transactions are more safe. At the same time, service providers need to consider security as part of their service offerings although the costs may be increased.

To enhance customer experiences, banks should not only focus on improving the Internet banking transactions but should also develop a better system or platform to interact with Internet banking adopters. This effort will help the banks to build a strong relationship with the adopters and indirect word-of-mouth will create a positive image for the banks. It appears that, the service providers must sure that the Internet banking is user-friendly and has simple instructions to conduct the transactions.

\section{Limitation and Future Research}

There are few limitations in this study. Firstly, since the majority of banks in Malaysia are reluctant to disclose their customer profiles, this survey does not specifically interview the adopters or users of larger number of banks. Secondly, this study target the repondent groups with IT knowledge and hence larger number of customers were not included. Thirdly, this study investigates only the few factors that are strongly believed to have an influenced on the Internet banking adoption hence there are other factors that can be included in future studies. Lastly, since there are limited studies have investigated the Internet banking usage in Malaysia, the effect of the backgound of the respondents were not examined. Additionally, future research should also examine other factors such as relative advantage, costs and promotion.

\section{Conclusion}

The aim of this research is to investigate the factors that influence adopters to adopt Internet banking in Malaysia. 116 questionnaires were used for data analysis. This research has shown that Complexity, Perceived Security, Customer Experience and Individual Characteristics (income \& education level) influence the adoption of Internet banking.

These findings may help the policy makers and service providers to arrive at better policies and strategies for future development in Internet banking or mobile banking. The service providers should play more attention to the security aspects in Internet banking. This is mainly due to Security, being is the main concern among the adopters. It also can be a major reason why some bank customers are not willing to adopt Internet banking. Without a clear understanding of online banking usage, banks need to put more efforts to improve their Internet banking services.

\section{References}

Awamleh, R., \& Fernandes, C. (2006). Diffusion of Internet banking amongst educated consumers in high income non-OECD country. Journal of International Banking and Commerce, 11(3).

Brown, I., Hoppe, R., Mugera, P., Newman, P., \& Stander, A. (2004). The Impact of national environment on the adoption of Internet banking. Journal of Global International Management, 12(12), 1-26. http://dx.doi.org/10.4018/jgim.2004040101

Chan, S. C., \& Lu, M. T. (2004). Understanding Internet banking adoption and use behavior: a Hong Kong perspective. Journal of Global Information Management, 12(3), 21-23. 
http://dx.doi.org/10.4018/jgim.2004070102

Foon, S. Y., \& Fah, Y. C. (2011). Internet banking adoption in Kuala Lumpur: an application of UTAUT model. International Journal of Business and Management, 6(4), 161-167.

Gerrard, P., \& Cunningham, B. J. (2003). The diffusion of Internet banking among Singapore consumers. International Journal of Bank Marketing, 21(1), 16-28. http://dx.doi.org/10.1108/02652320310457776

Hernandez, C. M. J., \& Mazzon, A. J. (2007). Adoption of Internet banking: proposition and implementation of an integrated methodology approach. International Journal of Marketing, 25(2), 72-88.

Jaruwachirathanakul, B., \& Fink, D. (2005). Internet banking adoption strategies for a developing country: the case of Thailand. Internet Research, 15(3), 295-311. http://dx.doi.org/10.1108/10662240510602708

Karjaluoto, H., Mattila, M., \& Pento, P. (2002). Factors underlying attitude formation towards online banking in Finland. International Journal of Bank Marketing, 20(6), 261-272. http://dx.doi.org/10.1108/02652320210446724

Kolodinsky, M. J., Hogarth, M., \& Hilgert, A. M. (2004). The adoption of electronic banking technologies by US consumers. International Journal of Bank Marketing, 22(4), 238-259. http://dx.doi.org/10.1108/02652320410542536

Laforet, S., \& Li, X. Y. (2005). Consumers' attitudes towards online and mobile banking in China. International Journal of Bank Marketing, 23(5), 362-380. http://dx.doi.org/10.1108/02652320510629250

Lassar, M. W., Xavier, M. C., \& Lassar, S. S. (2005). The relationship between consumer innovatiness, personal characteristics, and online banking adoption. International Journal of Bank Marketing, 23(2), 176-199. http://dx.doi.org/10.1108/02652320510584403

Lee, J. L., Lee, K. T., \& Eastwood, D. (2003). A two-step estimation consumer adoption or technology-based service. Journal of Consumer Affairs, 296-27. http://dx.doi.org/10.1111/j.1745-6606.2003.tb00453.x

Malhotra, K. N. (2007). Marketing Research: an applied orientation (5th ed.). United State: Pearson.

Ndubisi, O. N., \& Sinti, Q. (2006). Consumer attitudes, systems characteristics and Internet banking adoption in Malaysia. Management Research News, 29(1/2), 16-27. http://dx.doi.org/10.1108/01409170610645411

Ng, R. (2011). Malaysians the biggest online banking users in Southeast Asia. The Edge.

Norazah, M. S. (2010). An empirical study of factors affecting the Internet banking adoption among Malaysian consumers. Journal of Internet Banking and Commerce, 15(2).

Perumal, V., \& Shanmugam, B. (2004). Internet banking: boon or bane? Journal of Internet Banking and Commerce.

Pikkarainen, T., Pikkarainen, K., Karjaluoto, H., \& Pahnila, S. (2004). Internet Research, 14(3), 224-235. http://dx.doi.org/10.1108/10662240410542652

Polasik, M., \& Wisniewski, P. T. (2009). Empirical analysis of Internet banking in Poland. International Journal of Bank Marketing, 27(1), 32-52.

Polatoglu, V. N., \& Ekin, S. (2001). An empirical investigation of the Turkish consumers' acceptance of Internet banking services. International Journal of Bank Marketing, 19(4), 156-165. http://dx.doi.org/10.1108/02652320910928227

Sabbagh, A. I., \& Molla, A. (2004). Adoption and use of Internet banking in the Sultanate of Oman: an exploratory study. Journal of Internet Banking and Commerce.

Sathye, M. (1999). Adoption of Internet banking by Australian consumer: an empirical investigation. International Journal of Bank Marketing, 17(7), 324-334. http://dx.doi.org/10.1108/02652329910305689

Shao, G. S. (2007). The diffusion of online banking: research trends from 1998-2006. Journal of Internet Banking and Commerce.

Shih, Y. Y., \& Fang, T. K. (2004). The use of the decomposed theory of planned behavior to study Internet banking in Taiwan. Internet Research, 14(3), 213-223. http://dx.doi.org/10.1108/10662240410542643

Sugathi, B., \& Balachandran. (2001). Internet banking patronage: an empirical investigation of Malaysia. Journal of Internet Banking and Commerce, 6(1).

Tan, M., \& Teo, H. S. (2000). Factors influencing the adoption of Internet banking. Journal of the Association 
for Information Systems, 1(5), 1-42.

Zafar, S. N., \& Jay, D. (2002). Want more web biz? American banker, 167(114).

\section{Copyrights}

Copyright for this article is retained by the author(s), with first publication rights granted to the journal.

This is an open-access article distributed under the terms and conditions of the Creative Commons Attribution license (http://creativecommons.org/licenses/by/3.0/). 